\title{
Solar Activity and its Stronger Magnetic Field Stimulated the Human Brain and Brought the Renaissance
}

\author{
Maria Kuman* \\ Holistic Research Institute, USA \\ *Corresponding author: Maria Kuman, Holistic Research Institute, Knoxville, USA \\ To Cite This Article: Maria Kuman. Solar Activity and its Stronger Magnetic Field Stimulated the Human Brain and Brought the Renaissance. \\ Am J Biomed Sci \& Res. 2019 - 4(6). AJBSR.MS.ID.000845. DOI: 10.34297/AJBSR.2019.04.000845
}

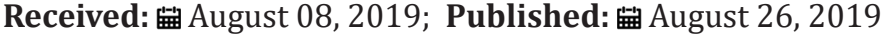

\begin{abstract}
Renaissance was the period of blooming arts, literature, architecture, and the sciences in the middle of the last Mini Ice Age $\left(15^{\text {th }}\right.$ and $16^{\text {th }}$ centuries). Based on study of the glaciers, the article provides evidence that the Renaissance was caused by increased solar activity and sudden warming in the middle of the last Mini Ice Age. Increased solar activity always means increased magnetic field of the Sun, which increases the magnetic field of the Earth. Since our memory is magnetic in origin, external magnetic fields stimulate the brain and memory. If so, the increased magnetic fields of the Sun and Earth during the warming period in the $15^{\text {th }}$ and $16^{\text {th }}$ centuries could be expected to be the factor that stimulated the human brains. This boosted their creativity and caused the blooming of the arts, literature, architecture, and the sciences called the Renaissance.
\end{abstract}

Keywords: Increased solar activity; Increased solar magnetic Field; Increased earth magnetic field; Increased brain stimulation; Renaissance.

\section{Introduction}

'Renaissance' is a French word and means 'born again'. The time of the $15^{\text {th }}$ and $16^{\text {th }}$ centuries was called Renaissance and it was like spring awakening in the middle of a winter. It was preceded by a culturally darker period and it was followed by a culturally darker period. Characteristic for it was blooming of the arts, literature, architecture, and the sciences. What did cause the Renaissance or the rebirth? What did cause the awakening? Different people have different beliefs. Michael Baigent and Richard Leigh believed [1] that after the Ottoman Turks captured Constantinople in 1453 A.D. many of the Byzantine elite immigrated to Rome and this caused the Renaissance. Some Byzantine scholars did seek a refuge in Rome, but no one of the famous Renaissance names of the 16th century was from Byzantium. Leonardo da Vinci, Michelangelo, and Galileo Galilee were all local Romans. They were not immigrants from Constantinople. So, immigrating Byzantine elite did not cause the Renaissance. Also, Europe started to awaken as early as $11^{\text {th }}$ and $12^{\text {th }}$ century, which preceded the Renaissance. It was marked by building of Gothic architecture and opening of a chain of Universities: the University of Bologna (1088) and the University of Modena (1175) in Italy, the University of Paris in France (1150), the University of Oxford in England (1096), etc. [2]. If migrating elite from Constantinople did not cause the Renaissance, what did it?

\section{Increased Solar Activity -> Increased Magnetic Field -> Increased Brain Activity -> Renaissance}

Being a biophysicist, I see things this way. Since our memory is magnetic in origin, external magnetic fields stimulate our memory and our brains. Studies at the Department of Biophysics at Moscow University around 1970 showed that magnetic fields influenced imaging. A person under hypnosis was imagining holding a pigeon in his hands. When a magnet was approached to his head, the image disappeared [3]. Recent studies of 2011 confirmed that magnetic fields influence our brain [4].

Figure 1 from study of the glaciers [5] reflects the temperature changes during the period 900-1900 A.D., which includes the last Mini Ice Age (1350-1800 A.D.). This study of the glaciers shows [5] that there was substantial warming right in the middle of the Ice Age in the $15^{\text {th }}$ and $16^{\text {th }}$ century (1500 A.D.-1600 A.D.), which is the Renaissance period. Warming around $15^{\text {th }}$ century AD means that there was increased solar activity, which goes hand in hand with increased magnetic field of the Sun and consequently the Earth. Both stimulated the human brain and its creativity, which led to the blooming arts, literature, architecture, and the sciences called the Renaissance. This was the period of Leonardo da Vinci, 
Michelangelo, Galileo Galilee, etc. in Italy, but Renaissance was also taking place in France, Holland, England, etc. [6].

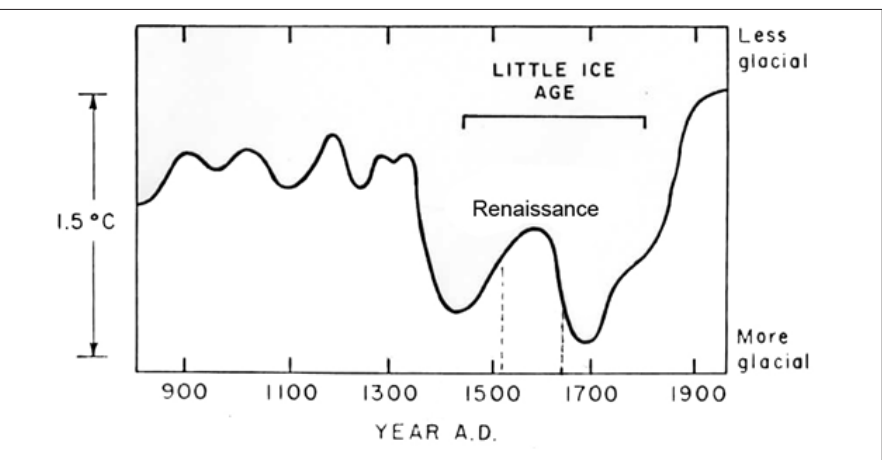

Figure 1: The temperature variations on earth from $900 \mathrm{AC}$ to 1900 AC [5].

\section{Correlations between Temperature (Magnetic) Changes and Historic Events}

There is a strong correlation between the temperature changes on Figure 1, which correlate with magnetic changes, and the historic events happening during this time period. 1/ The opening of the Universities took place during the third peak of temperatures, which is more pronounced than the first two. 2/ The steep drop in temperature in early $14^{\text {th }}$ century, which indicates fast decrease of solar activity and magnetic field, was a period of famine (13151317). The famine and the deadly plague Black Death reduced the population to half of what it was. This was also the time of uprising of the peasants in France and England and the time of the 100-year war between France and England, which Joan of Arc ended [6]. The minimum of temperatures around 1700 A.D. means very low solar activity and magnetic field. When the solar activity is low and there is no enough magnetic field to stimulate the human brain expect global dumbness. Indeed, Gerald J. Toomer [7] writes in his book John Seldon: A Life in Scholarship that suddenly in the 17th and 18th centuries everybody became dumb for unknown reason [7].

The dumbing factor must have been substantial. Thus, it is not the struggle to survive in the cold winter what caused the lack of interest in art, science, and architecture. One more factor needs to be considered: the human body responds in a dramatically different way to low-intensity stressors and high-intensity stressors. It is called biphasic reaction [8-9]. The same stressor (in this case magnetic field, but it could be any stressor) when mild stimulates, but when strong it harms or causes pathology because the body fails to adapt to it. Obviously, mild changes in the magnetic field (like those during the Renaissance) stimulate the brain, but drastic changes in the magnetic field (like those before and after the Renaissance) are too big to adapt to, which impair the whole body including the brain. After the Renaissance, in the $17^{\text {th }}$ and 18th centuries, when the temperatures were increasing very fast and with them the solar activity and the solar magnetic field and the human body couldn't adapt to the fast changes, turmoil took place expressed in a chain of French revolutions. The First French Revolution of 1789 ended the absolute monarchy that ruled France for millennia in just three years. Republic was proclaimed in September 1792 and King Ludwig XVI was executed the next year [6].

But the Republic didn't last long because Napoleon Bonaparte started his successful wars in 1793, which prompted him to pronounce himself Emperor in 1804. However, the Russian General Kutuzov defeated him in 1812, which started his defeat, and he was finally defeated at Waterloo in June 1815 [6]. Napoleon was exiled on island St. Elena and the Bourbon monarchy was restored to power, but this time as a constitutional monarchy. Since monarchs don't like restricted power, many attempts were made to disregard or disassemble the elected constitutional assembly. This led to the July 1830 Revolution in France, which created the Second French Republic [6]. The Napoleon Wars (1799-1815 A.D.) did one good thing, they ended the Holy Roman Empire in Europe centered in the Vatican, but they saw the seeds of nationalism in Germany and Italy, which led to their consolidation at the end of the century and the First World War at the beginning of the next century [6].The next French Revolution was in 1848, after which Louis Napoleon, nephew of Napoleon Bonaparte, was elected president of the Third Republic. Three years later, in 1851, he initiated coup d'état, suspended the elected constitutional assembly, and pronounced himself emperor, thus establishing the Second French Empire. The Empire existed until the French Revolution of 1871 [6]. The Paris Commune of 1871 pronounced the Fourth French Republic, which also didn't last long. Thus, during the period of fast rising temperatures and fast rising solar activity and magnetic field at the end of the last Mini Ice Age, the French had four revolutions and none of them brought the desired liberal democracy. The following First World War ended this disastrous period of rebellions and wars for a while [6].

\section{Conclusion}

I hope the provided facts have convinced you that drastic changes in the solar activity manifested in drastic changes of the magnetic field of the Sun influences not only the temperatures on Earth, but also the human health, brains, and activities.

\section{References}

1. Michael Baigent, Richard Leigh (1989) The Temple and the Lodge NY.

2. Charles H. Haskin (1957) The Rise of Universities, Ithaca.

3. Maria Kuman (1996) A Guide to the Mind's Secrets, Health and Happiness Books.

4. Ueno S (2011) Recent Advances in Transcranial Magnetic Stimulation, Proceedings of IEEE.

5. John and Katherine Imbri Hillside, NJ (1979), Ice Ages: Solving the Mystery.

6. Jawaharlal Nehru (1932) Glimpses of World History.

7. Toomer GJ (2009) John Seldon: A Life in Scholarship.

8. Maria Kuman (1998) Stress as Killer, Stress as Healer, Health and Happiness Books.

9. Maria Kuman (1993) What Everybody Ought to Know about Chronic Pain, Chronic Diseases and Cancer Health and Happiness Books. 